MATEC Web of Conferences 3, 01044 (2013)

DOI: $10.1051 /$ matecconf/20130301044

(C) Owned by the authors, published by EDP Sciences, 2013

\title{
Study of the chemical inhibition of the scaling of large Agadir water
}

\author{
A. Driouiche, A. Hadfi, H. Eddaoudi, and M. El Hadek \\ Laboratory of Chemical Engineering, Faculty of Science, University Ibn Zohr, P.O. Box 8106, Agadir, Morocco
}

\begin{abstract}
The distribution mains of drinking water of Large Agadir are the seat of chemical scaling. This phenomenon is due primarily to the precipitation of calcium carbonate. The effectiveness of two chemical inhibitors containing phosphorus was quantified on underground water samples of the area of Agadir. The effective concentrations of these two inhibitors were given.
\end{abstract}

\section{Experimental results}

\subsection{Physico-chemical characterization of water chosen}

The samples studied were collected at source, prior treatment for drinking water, in the well No. 894/69 belonging to the said wellfield Golf [1]. These samples have a strong tendency to scaling with a germination time of $16 \mathrm{~min}$ and a speed of scaling 1.62.10-2 1 / min [2].

The results of physicochemical analyzes are given in Table 1. Examination of these results shows that water is a very busy $\mathrm{Ca}^{2+}\left(\left[\mathrm{Ca}^{2+}\right]=50.5^{\circ} \mathrm{F}\right)$. It is also rich in bicarbonate $\left(\mathrm{TAC}=32{ }^{\circ} \mathrm{F}\right)$. In addition, the samples exhibit a particularly high salinity due to high concentrations of chlorides.

Table 1. Physical-chemical parameters of water selected in the region of Agadir.

\begin{tabular}{c|ccccccccc}
$\begin{array}{c}\text { Origin } \\
\text { water }\end{array}$ & $\begin{array}{c}\mathrm{TH} \\
\left({ }^{\circ} \mathrm{F}\right)\end{array}$ & $\begin{array}{c}\mathrm{TAC} \\
\left({ }^{\circ} \mathrm{F}\right)\end{array}$ & $\begin{array}{c}\mathrm{Ca}^{2+} \\
(\mathrm{mg} / \mathrm{l})\end{array}$ & $\begin{array}{c}\mathrm{Mg}^{2+} \\
(\mathrm{mg} / \mathrm{l})\end{array}$ & $\begin{array}{c}\mathrm{K}^{+} \\
(\mathrm{mg} / \mathrm{l})\end{array}$ & $\begin{array}{c}\mathrm{Na}^{+} \\
(\mathrm{mg} / \mathrm{l})\end{array}$ & $\begin{array}{c}\mathrm{Cl}^{-} \\
(\mathrm{mg} / \mathrm{l})\end{array}$ & $\begin{array}{c}\mathrm{SO}_{4}{ }^{2-} \\
(\mathrm{mg} / \mathrm{l})\end{array}$ & $\begin{array}{c}\mathrm{D} . \mathrm{R} \\
(\mathrm{g} / \mathrm{l})\end{array}$ \\
\hline $\begin{array}{c}\text { Well } \mathrm{n}^{\circ} \\
894 / 69\end{array}$ & 92 & 32 & 202 & 101 & 5 & 245 & 653 & 200 & 1.85 \\
& & & & & & & &
\end{tabular}

One French degree corresponds to $10 \mathrm{mg}$ of $\mathrm{CaCO}_{3}$ potentially dissolved (or $4 \mathrm{mg}$ of $\mathrm{Ca}^{2+}$ ) per liter.

TH: total hardness $=\left[\mathrm{Ca}^{2+}\right]+\left[\mathrm{Mg}^{2+}\right]$

TAC: total alkali $=\left[\mathrm{HCO}^{3-}\right]+2 \cdot\left[\mathrm{CO}^{3=}\right]+\left[\mathrm{OH}^{-}\right]$

D.R.: dry residue

\subsection{Chemical scaling inhibition}

Inhibitors tested in this study are the phosphonate known under the trade name "RPI 3000" and inorganic phosphate "STPP" which are products available in the local market. The study is to add increasing amounts of the inhibitor to the water sample and measure over time the $\mathrm{pH}$ and the concentration of $\mathrm{Ca}^{2+}$.

For the phosphonate "RPI 3000", germination time is multiplied by 3 and 5 for concentrations 0.3 to $0.7 \mathrm{ppm}$.
At a concentration of $0.9 \mathrm{ppm}$, there is no longer germination during the period of manipulation.

The critical value of $\mathrm{pH}$ of the solutions treated with increasing concentrations of RPI 3000, it rose from 8.68 to $8.94 \mathrm{ppm}$ for 0 to $0.7 \mathrm{ppm}$. The drop in $\mathrm{pH}$ occurs much for the test without inhibitor, whereas for increasing concentrations, the fall becomes less remarkable but it exists for concentrations up to $0.7 \mathrm{ppm}$. From $0.3 \mathrm{ppm}$ yields a level, which proves that the duration of the germination phase becomes longer and longer than degassing.

For inorganic phosphate STPP, the germination time is multiplied respectively by 1.6 and 4 , compared to the control test, for contents of STPP 0.2 and $0.4 \mathrm{ppm}$. At a concentration of $0.6 \mathrm{ppm}$, we don't observe the precipitation during the test period (effective concentration). For this concentration, the germination time does not exceed 84 minutes in the case of RPI 3000.

The $\mathrm{pH}$ at the point of germination is becoming increasingly important relative to that obtained by adding the 3000 RPI. It reached 8.93 to $0.4 \mathrm{ppm}$ STPP then it does not exceed 8.9 to 0.5 ppm 3000 RPI. At 0.4 ppm, we obtain a plateau before the precipitation, which proves that the duration of the germination phase exceeds that of degassing.

\section{Conclusion}

The role of two chemical inhibitors of scaling has been clearly demonstrated by the method "LCGE". For both inhibitors, despite a scaling power of the water in question, the effective concentrations of 0.9 and $0.6 \mathrm{ppm}$ in 3000 and RPI respectively STPP prevents precipitation of calcium carbonate under the conditions of the experiment. 


\section{References}

1. A. Driouiche, M. El Hadek, K. Walha, M. Ben Amor,

B. Tanouti, Ann. Chim. Mater Sc. 25 (S1) 371 (2000)

2. A. Driouiche, A. Mazola, M. Ben Amor, M. El

Hadek, B. Tanouti, Water Tribune, 610/2 57 (2001) 